\title{
TRANSCULTURAL AND TRANSCONTINENTAL TELECOLLABORATION FOR FOREIGN LANGUAGE LEARNING: PROPOSALS AND CHALLENGES
}

\author{
Leila Martins Gonçalves da COSTA ${ }^{1}$ \\ Ana Cristina Biondo SALOMÃO2 \\ Maisa de Alcântara ZAKIR ${ }^{3}$
}

Proposals that focus on student-centered approaches and not only on the role of the teacher have gained space in the area of foreign language teaching and learning since the 1980's, by activities aiming at promoting interaction and negotiation of meaning. For Crandall (2000), this type of collaboration promotes positive affective aspects like reduction in anxiety, increase in motivation and self-esteem, development of positive attitudes towards learning in general, as well as exposure to different styles of learning. In this sense, learners benefit from collaboration and help from their peers, and teachers do not position themselves as the authority and producer of knowledge in the classroom.

The first reports of online collaborative projects between learners from different places only started in the 1990's, when language teachers and learners had access to the internet more regularly (O'DOWD, 2007). Nevertheless, the idea of engaging students from different places in collaborative activities had already been practiced long before the 1990's. There are reports from the 1920's about the French educator Célestin Freinet conducting a project with his students to produce newspapers that were later exchanged with students from other parts of France, who had also created newspaper articles (KERN, 2013; O'DOWD, 2007).

\footnotetext{
1 Costa. University of Miami. E-mail: leilamiami@gmail.com. ORCID ID: https://orcid.org/0000-0001-8039$211 X$

2 Salomão. UNESP. E-mail: ana.salomao@unesp.br. ORCID ID: https://orcid.org/0000-0002-1531-8551

3 Zakir. UNESP. E-mail: maisa.zakir@unesp.br. ORCID ID: https://orcid.org/0000-0002-1792-3026
} 
- | Transcultural and Transcontinental Telecollaboration for Foreign Language Learning: proposals and challenges

O'Dowd (2018) describes telecollaboration as the engaging of a group of learners in intercultural online interactions and collaboration projects with partners from other cultural contexts or other geographical spaces as an integral component of educational programs. The author explains that different terminologies have been used in the past to name this kind of activity, such as online intercultural exchange, virtual exchange, COIL (Collaborative Online International Learning), internet-mediated intercultural foreign language education, globally networked learning environments, e-tandem and teletandem.

We agree with the author that the amount of different projects is positive because it shows that this modality of learning has been implemented extensively in different ways and has been adapted to different contexts and geographical spaces. Yet, this also shows that the practices and research results of these similar initiatives are not known by members of the academic community from different or related areas. O'Dowd (2018) also mentions the challenge that the different terminologies and approaches bring to the promotion and dissemination of these activities among educators and administrators that are not familiar with these concepts.

Currently, there are various telecollaborative projects ranging from individual proposals, conducted by teachers in their classrooms, to interinstitutional projects, which have recognition and, many times, resources for their execution. There are also international platforms like eTwinning (MIGUELA, 2007), which coordinate contacts among education professionals who work in schools from different countries so that they can communicate, collaborate and create projects together. ${ }^{4}$

There are projects that combine language learning with a cultural component, like the Cultura Project, originated in 1997 at MIT, by Gilberte Furstenberg, Shoggy Waryn and Sabine Levet (GARCÍA; CRAPOTTA, 2007). Their objective is to connect groups of students through the internet for cultural exchange, using on-line questionnaires, which are later analyzed, as well as forums in which the groups discuss cultural values and beliefs based on the answers given on the questionnaires. ${ }^{5}$

Other current online telecollaboration projects and websites are: eTandem Europa ${ }^{6}$, from Ruhr-University Bochum, in Germany, which has the objective of promoting language learning through eTandem, and offering the interested parties support for finding a partner;

4 For more information, see: https://www.etwinning.net/pt/pub/index.htm.

5 For more information, see: https://cultura.mit.edu/.

6 For more information, see: http://www.ruhr-uni-bochum.de/tandem-server/etandem/etindex-en.html 
Lingalog ${ }^{7}$, from Université Lumière Lyon II, in France, which also offers collaborative work for learning languages by connecting natives of different languages through a platform providing them technological tools, such as forum, chat and wiki; INTENT ${ }^{8}$ (Integrating Telecollaborative Networks into Foreign Language Higher Education), a project developed in many Higher Education institutions around the world, which, from a platform, gives support to university professors and promotes telecollaboration projects among their students; TILA ${ }^{9}$ (Telecollaboration for Intercultural Language Acquisition), a European Commission Project that uses the platform Moodle and consists of an international community of teachers and researchers interested in innovating and enriching practices of language learning, integrating telecollaboration activities with partners from different countries; Tandem Exchange ${ }^{10}$ e ePals ${ }^{11}$, websites that connect people so that they can work in collaboration, online and face to face

O'Dowd (2014) cites examples of projects that include discussions in newspapers and magazines in international forums, like the ones in Le Monde or The Guardian, which go beyond learner interaction and provide opportunities of "authentic" communication, requiring knowledge of cultural codes and registers of this particular genre. The author also mentions initiatives like "Telecollaboration 2.0", based on resources of the "social web" that emerged from the creation of collaborative tools on the internet, like blogs, wikis and social media like Facebook, Instagram, among others, which could provide more independent initiatives in the classroom if compared to previous models.

As far as language learning is concerned, we would like to highlight the projects eTandem (O'ROURKE, 2007), and Teletandem (TELLES, VASSALLO, 2006; TELLES, 2009), which pair up speakers of different languages to work in a collaborative manner by synchronous or asynchronous communication on the Internet in order to learn each other's language. In eTandem, the interaction is done using chat while in Teletandem the focus is on oral comprehension and production with the use of VOIP technology (Voice over Internet Protocol), like Skype and, more recently, Zoom.

The articles included in this thematic issue focus mainly on these two last modalities of telecollaborative learning. Therefore, in the next section, we present an overview of these two modalities in order to discuss their respective characteristics as well as reflect on their implications for foreign language teaching and learning presently.

\footnotetext{
7 For more information, see: http://lingalog.net/dokuwiki/

8 For more information, see: http://www.uni-collaboration.eu/

9 For more information, see: http://www.tilaproject.eu/moodle/

10 For more information, see: https://www.tandemexchange.com/

11 For more information, see: www.epals.com
} 
- | Transcultural and Transcontinental Telecollaboration for Foreign Language Learning: proposals and challenges

\section{From Tandem to Teletandem ${ }^{12}$}

Tandem is the name given to the bicycle that has two seats and two sets of pedals, on which two people ride together in order to make it move. The functioning of the bicycle depends on the effort the riders dedicate to the process together. This is a metaphor for the collaboration between partners involved in the context of in-tandem learning. According to Vassallo and Telles (2006), this concept of learning originated in Germany in the 1960's and was based on the promotion of partnerships among speakers of different languages so that each partner would learn each other's language. The authors explain that only in the 1970's in Spain the name Tandem was used to characterize this language learning modality and the systematization of its principles effectively occurred during the 1990's (BRAMMERTS, 1996).

Vassallo and Telles (2006) state that the Tandem curriculum emerges from the needs and involvement of the partners. According to the authors, the tandem-learning context offers opportunities for socialization and individualization, since it is based on autonomy, i.e., understood as responsibilities for decision making by both tandem partners, not individually. They also state that, in Brazil, Tandem was barely practiced face-to-face due to difficulties to arrange meetings between native speakers of different languages, for example, in Europe, where Tandem emerged and became popular mainly in academic contexts. The authors also point out that the expansion of the Internet and the use of e-mails for communication have brought popularity for the tandem regime in computer-mediated language learning in Brazil and that technological advances in synchronous communication have opened up new possibilities of interaction for remote tandem sessions.

Vassallo and Telles (2006) proposed the context of "Teletandem", in which tandem collaborative learning would take place through digital tools on the internet, like applications for online communication using audio, video and chat. The authors, who, at the time, were face-to-face tandem partners in order to learn Portuguese and Italian, reveal that the idea for this new online modality emerged when Vassallo had to go back to Italy, and they thought of new ways to continue their communication overseas. At first, they decided for asynchronous e-tandem, via e-mail, but Vassallo and Telles missed their oral interaction since this medium allowed written production and reading only. They searched and found tools for instant communication on the Internet, like MSN Messenger, the most

12 We chose to write the words Tandem and Teletandem using a capital letter when they refer to the concept or to the Project and in lower case when they refer to the practice or context of such modality. In citations and references, we kept the way they were used by the original authors. 
commonly used and available in 2005 and 2006. The authors mention that when they tested this tool for learning in tandem between them and with their friends, they thought the results were practical, interesting and affordable. That is how the Project Teletandem Brasil: Línguas estrangeiras para todos (Foreign languages for all) started. The aim of the project was to investigate the new learning modality that they were experimenting and its possible implications for education.

The Teletandem Brasil Project ${ }^{13}$ (TELLES; VASSALLO, 2006; TELLES, 2009; BENEDETTI; CONSOLO; VIEIRA-ABRAHÃO, 2010), which was sponsored as a thematic project by FAPESP (process 06/03204-2), had as its main objective to connect partners/ speakers from different languages working in collaboration, using resources of synchronous communication on the Internet, like Skype, in order to learn each other's languages. Moreover, as the authors placed this language learning modality in perspective for future use, the project aimed specifically at investigating: (1) the use of online communication tools as a pedagogical instrument for remote tandem language learning; (2) the linguistic, cultural and pedagogical characteristics of the interaction between learning partners; and (3) the initial education of student-teachers (mainly students from the Language and Literature courses) involved in the interactions and the role of the mediator in this context.

From a theoretical point of view, the fundamental principles that underlie learners' partnerships in tandem and teletandem are the principle of equality (or separation of language $\mathrm{s}^{14}$ ), reciprocity and autonomy. There is also the projection of pedagogical support from a mediator to help practitioners with their learning development, as we will detail later.

The principle of equality determines that tandem sessions should have two equal parts: each participant has to commit to using the foreign language which he/ she is learning and his/her native language, but never during the same part of the session so that both partners may have equal opportunities to practice the foreign language. The principles of reciprocity and autonomy together determine that each partner will be responsible for his/her own learning process and the other person's learning and that both have to work together and choose the best methods to achieve their goals.

13 This Project, created by Prof. Dr. João Telles, from FCL/ UNESP Assis, is jointly developed in this institution, at IBILCE/UNESP in São José do Rio Preto, and FCL/UNESP in Araraquara. For more information, see: http:// www.teletandembrasil.org and http://teletandem.wixsite.com/fclar.

14 According to Telles and Vassallo (2006), the languages should not be mixed, and therefore, the authors denominate this principle in teletandem as separation of languages. In this way, each of the practitioners should benefit from the partnership by guaranteeing the same length of time for the practice of both languages. In addition, there is a recommendation that each session begin with one language, thus ensuring that both learners have access to begin the interaction in the target language. 
- | Transcultural and Transcontinental Telecollaboration for Foreign Language Learning: proposals and challenges

Little (2002) states that the principles of reciprocity and autonomy in tandem only make sense if they are practiced together since the goal of the partnership will only be achieved if both telecollaborators become responsible for their own and for their partners' learning. According to Salomão, Silva and Daniel (2009), the principles are interdependent because reciprocity helps the separation of languages and fosters equal opportunities of practice for both partners ${ }^{15}$. For the authors, reciprocity is also part of collaborative autonomy co-constructed during the interaction, as the partners work together to understand and define their needs as well as to decide the practices that will lead them to achieve their goals. In this way, autonomy in this context does not mean individual decision making but in collaboration with the other person.

The relationship between partners is what constitutes teletandem practice being, thus, responsible for the success of the interaction sessions. The interaction is the moment in which the partners help each other in the learning process. It is the space for reciprocal and collaborative exchanges that go beyond the limits of a trivial conversation: the participants have to be attentive to the content of the conversation but also to the language form in their turns. The duration of the session is defined by the participants, in the case of non-institutional modalities. In modalities of institutional teletandem, which take place mainly in groups, the duration varies according to the duration of the classes, usually from 50 to 75 minutes.

The literature on (Tele)Tandem presupposes pedagogical support by a teacher/ counselor (in teletandem, it was called mediator) who will be responsible for the organizational, theoretical and practical functioning in which the whole process will take place. Authors such as Little (2002), Brammerts, Calvert and Kleppin (2002), and Stickler (2003) mention the need for counseling sessions for the participants of collaborative learning in tandem. According to them, in spite of the learner's motivation for this kind of work, he or she may not be able to totally explore the potential that the context offers. Therefore, it is necessary to motivate practitioners to use their own abilities to learn independently and collaboratively and to reflect on their own learning processes, making decisions and revising them continually, and finally evaluating their learning progress.

For Brammerts, Calvert e Kleppin (2002), counseling sessions are necessary because many learners may not be aware of all the factors conducive to their decision making, like objectives, habits, opportunities, preferences, etc. According to the authors, it is not always easy for learners to translate their decisions into action, so their proposal goes toward reflection, culminating in the search for learner autonomy. The counselor must formulate

15 Partner is the name used to refer to a teletandem participant. In this article, we use partner, participant and practitioner interchangeably. 
questions that could elicit relevant elements for the participants' decision-making as far as their presuppositions, objectives and the changes that have taken place in their practice, helping them to make connections. In this way, the counselor will introduce his/her knowledge, experience and expertise without controlling the participant's practice.

Stickler's (2003) proposal also involves aspects related to counseling which lead the learner toward autonomy using exploration and reflection. The author offers a list of suggestions about do's and don'ts for the counselor generally concerning exploratory but not authoritative behaviors in relation to the learner, suggesting a more pragmatic view, which will be improved by the counselor in his/her practice.

In the Teletandem Brasil Project, counselling sessions of partnerships are called mediation sessions (TELLES; VASSALLO, 2006), based on sociocultural theory. Mediation has been done in different ways by graduate and undergraduate students with knowledge and experience in teletandem through individual or group sessions as well as reflective journals, in narratives or in dialogues, hosted in virtual learning websites like Moodle, Teleduc, Google classroom, Blackboard, and more recently even in social media like Facebook.

According to Williams and Burden (1999), the word "mediation", in the teaching and learning process, refers to the role of a significant person in the students' lives that selects and plans the procedures and experiences that will result in learning. We believe, as Salomão (2011) has observed, that the idea of mediation instead of counseling, used by the Teletandem Project, considers the support given by the mediator, not only as advice about procedures in order to better learn but as the introduction of a third person that becomes part of the collaborative teaching and learning, guiding participants to reflect upon their own practice as learners of the target language and teachers of their own language.

Salomão (2008) defines the figure of the mediator as a more competent partner that will mediate, in Vygostskyan terms, the practitioner's learning process, by offering mediation by instruments - using technological or non-technological resources -, and mediation by language, which permeates the process of interaction between the students involved. Telles (2005) resonates this idea by saying that mediation sessions are pedagogical support, performed by means of a reflective dialogue conducted by the mediators, who focus on learning strategies and linguistic and cultural aspects that emerge during the teletandem sessions. We agree with the author that the practice of conducting a mediation session requires knowledge about cultural encounters, discourse and communication from the mediators. 
- | Transcultural and Transcontinental Telecollaboration for Foreign Language Learning: proposals and challenges

Throughout the years, mediation has been performed in individual face-to-face sessions, as described in the research conducted by Salomão (2008), Mesquita (2008), Bedran (2008), Cavalari (2009), Funo (2015), Elstermann (2017), or in groups, as described by Carvalho, Messias and Días (2015), or even through videoconference, Facebook, and applications for group discussions (BEDRAN, 2012). There are also mediation experiences using dialogue-diaries on the Moodle platform (EVANGELISTA; SALOMÃO, 2019). Funo, Elstermann and Zakir (2016) have structured the practices performed by mediators in a teletandem context in an observation grid organized from open questionnaires answered by professors and researchers experienced in this area.

Considering the space occupied by the different telecollaboration projects in the scope of foreign language learning and teaching with the aim of generating a discussion on the impact of (tele)tandem learning in practice and research, the first International Meeting on Foreign Language Learning in tandem: Present, Past and Future (I INFLIT) took place at the University of Miami, in Coral Gables, Florida, USA, from February 27 to March 1, in 2014. The meeting was jointly organized by researchers from the Teletandem Brasil Project of São Paulo State University (UNESP), and from the Department of Modern Languages and Literatures from the University of Miami, USA, and had the participation of European, North and South-American researchers.

The opening lecture of the I INFLIT was presented by Dr. Karin Kleppin, from the University of Bochum, Germany. The researcher, who was a pioneer of Tandem learning in her country, talked about the history and evolution of Tandem and eTandem, and discussed the future of this context of foreign language learning.

The second edition of the event also took place at the University of Miami on March 22-24 in 2018. The second IMFLIT (now with M for "meeting" and not N) had the theme "Transcultural Language Learning: Toward Global Citizenship in (e)Tandem". The meeting also had the collaboration of researchers from the Teletandem Brasil Project, at UNESP, and the department of Modern Languages and Literatures at the University of Miami, and had special support from the director of the Portuguese Program, Dr. Steven F. Butterman, and the department chair, Dr. Lilian Manzor.

The theme of the opening lecture, presented by the creator of the project Teletandem Brasil, Dr. João Antonio Telles, was "Performativity and transculturality in foreign language learning". The event also had researchers from international institutions in the area of telecollaboration, who could debate their work in presentations that prioritized discussions among the participants of each session. In the roundtable, "(En)Gendering Diversity and Cultural Differences In Telecollaboration: Gender Identities and The Roles 
of Mediators and Professors", Dr. Steven Butterman, Dr. Ana Menda, from the University of Miami, and Ms. Ivian Destro, from Florida International University, held an important debate about how to deal with "difference" during the interactions in the classroom and online, promoting respect and tolerance in face-to-face and virtual encounters.

It was from all the discussions that took place during II IMFLIT that the idea of a thematic publication, whose articles are presented below, came up, focusing on the proposals and challenges brought by telecollaboration for language learning in the present time.

\section{Presentation of the thematic issue}

The thematic issue of Revista do Gel, "Transcultural and Transcontinental Telecollaboration for Foreign Language Learning: proposals and challenges", contains fifteen articles from Brazilian and foreign researchers, which are organized in four thematic axes: (i) face-to-face tandem context (ii); experiences from institutional telecollaborative partnerships; (iii) (self-)assessment, language practice and linguistic structure in teletandem learning; (iv) (inter)cultural, identity and subjectivity discussions.

The first thematic axis contains two articles. In "Face-to-face tandem and eTandem: differences that influence the maintenance of tandem learning activities", Masako Wakisaka compares two studies of multiple cases in face-to-face tandem and e-tandem between Japanese-English and Japanese-German partnerships. The results bring implications for the factors that influence the maintenance of activities in these collaborative learning contexts.

In "A deaf and a hearing student learning Portuguese and Libras in a tandem context", Francisco José Quaresma de Figueiredo and Quintino Martins de Oliveira present results from a study in face-to-face tandem about possible benefits of this approach to speakers of different language modalities: oral hearing (Portuguese) and visual-spacial (Libras Brazilian Sign Language). The authors analyze the telecollaborative strategies adopted and the negotiations established during the interactions.

The second thematic axis of this issue, which brings together works focusing on different aspects and characteristics of institutional partnerships, is composed of six articles. Karin Adriane Henschel Pobbe Ramos and Kelly Cristiane Henschel Pobbe de Carvalho, in "Estabelecendo objetivos de aprendizagem em contexto de Teletandem" (Establishing learning objectives in Teletandem context), discuss the use of learning 
- | Transcultural and Transcontinental Telecollaboration for Foreign Language Learning: proposals and challenges

objectives in a Teletandem context based on the Language Teaching for Specific Purposes approach, with a methodological background from Grounded Theory. The authors aim to provide "support to mediators and partners that are involved in this kind of online language teaching/learning context, so that they can direct and optimize the process by using the established objectives".

Edú Alberto Cruz Lecona and María Guadalupe Alfaro Martínez, in the article "El Teletándem en el aprendizaje alemán - español: Mediateca Enallt-Unam Y Universidad De Würzburg" ("Teletandem in German-Spanish learning - Mediateca Enalt-Unam and University of Wurzburg"), present the analysis of data obtained from the project Aprendizaje Virtual de Lenguas Extranjeras (AVLE - Virtual Foreign Language Learning), in which they evaluated students' performances in the German-Spanish teletandem. The authors discuss the results from performances of students, as well as the role of the language learning centers in each of the participating universities.

In the article "Experiencing teletandem: a collaborative project to encourage students in tandem interactions", Viviane Klen-Alves and Fernanda Franco Tiraboschi discuss the results of an action-research study that was carried out in collaboration between two teachers, one from a Brazilian secondary school and the other from an American technical school about "the potential of online in-tandem interactions for the enhancement of students' second language learning". According to the authors, the results indicate that telecollaborative activities promote positive attitudes and increase students' intercultural competence.

In the article entitled "Desenvolvimento da competência comunicativa oral em PLE: teletandem em foco" ("Oral communicative competence development in PFL: focusing on teletandem), Rozana Aparecida Lopes Messias and Michael Jones Ferreira discuss "to what extent Integrated Institutional Teletandem practice influences oral competence development" and investigate which aspects of the Teletandem participants' speech evidence improvement in their oral production.

As far as the concept of mediation in the institutional teletandem context is concerned, Daniela Nogueira de Moraes Garcia and Micheli Gomes de Souza, in their article entitled "Teletandem mediation on Facebook", discuss the pedagogical support to the participants using a closed group in a social network. The authors present "the results of an interpretativist qualitative analysis that shows the role of the mediator is focused on providing encouragement and guidelines based on teletandem theory and principles". 
Michael Abernathy Marsh-Soloway and Olivier Michel Delers, in "New directions in eTandem: an expanded vision of capabilities and practices", present three case studies from which they state that the traditional model of eTandem "can be enhanced with related tools and methodologies to engage students more deeply, and challenge them to push the boundaries of their language, abilities, and knowledge". Thus, the article "outlines ideas for instructors to commence new directions in eTandem, and consider improvements to long-standing practices".

There are three articles in the third axis, which focuses on assessment, language practice and linguistic structure in teletandem learning. In "A correção de erros e as relações entre avaliação por pares e autoavaliação no ambiente teletandem" (Error correction and the relationships between peer and self-assessment in teletandem), Suzi Marques Spatti Cavalari and Ana Carolina Freschi investigate error correction in the teletandem context, in an interpretative and qualitative study, that uses data from oral session recordings. The participants are three pairs of learners that interact in Portuguese and English. According to the authors, the analysis show that "that peer feedback involves not only the assessment made by the partner who is linguistically more competent, but also (and mainly) by the assessment made by the learner (self-assessment) of what is considered an error in his/ her oral production or comprehension".

In the article "Episódios relacionados à língua em interações deteletandem:implicações para a formação de professores de PLE" (Language-related episodes in Teletandem sessions: implications on the education of teachers of Portuguese as a foreign language), Gabriela Rossatto Franco discusses language-related episodes that emerge in the teletandem sessions by analyzing how Brazilian participants solve questions that their partners have about the Portuguese language. The author discusses the importance that "teletandem practitioners - who are future teachers of foreign languages - develop a reflective attitude towards language practices".

Edvan P. Brito, in "The variation of obligatory preposition-article contractions in the interlanguage of adult learners of Portuguese", analyses "a sociolinguistic variation of obligatory contractions between the preposition $d e$ and definite articles in the interlanguage of adult learners of Portuguese as a foreign language in the United States", demonstrating that "speech data from telecollaborative interactions can be used as one of the tasks in large scale interlanguage variation studies".

The fourth axis comprises four articles about (inter)culturality, identity and subjectivity issues. Aurora Castillo-Scott, in "Teaching social issues through cinema and teletandem", presents a pedagogical experience using cinema and teletandem to promote 
- | Transcultural and Transcontinental Telecollaboration for Foreign Language Learning: proposals and challenges

linguistic abilities touching on sociocultural topics, through conversations that focus on cultural, racial, gender and sociopolitical problems associated to Hispanic culture.

Kaitlin Teske and Alexis Vollmer Rivera, in "A critical exploration of heritage language learners' identities within HelloTalk", investigate how heritage language learners construct their identities in the e-tandem learning context, using the application HelloTalk. By examining participant-reported reflections and based on Content Analysis informed by Critical Applied Linguistics, "the results showed that although some features promote collaborative relations of power, in general the design of the application fosters coercive relations of power".

In "Deconstructing language learners' feelings of inferiority through teletandem", Paula A. Zulaica-Gómez investigates Mexican learners of English as a foreign language and discusses how "several sociocultural factors, resulting from the country's colonial history, affect their motivation and attitude towards English". The author analyses how these perceptions and attitudes towards English affect the willingness of Mexican learners to participate in teletandem sessions and how teletandem can break through these preconceived notions and change the way they perceive themselves and their partners.

Gerson Rossi dos Santos and Douglas Altamiro Consolo, in the article "Understanding Teletandem language learning from an intersubjective perspective", discuss the establishment of intersubjectivity in teletandem sessions from a hermeneutic perspective. The results show that the establishment of intersubjectivity encompasses both an immediate partner-to-partner dimension as well as a broader discourse communitybased dimension.

We hope that the articles in this thematic issue may contribute to the discussion of how the development of digital resources on the Internet has currently changed communicative practices around the world. It is important to remark that Kern, Ware and Warschauer (2004) had already suggested that this moment in language learning mediated by computers would be "a second wave", constituted mainly by telecollaboration guided by intercultural relations. This is reinforced by the many projects that have been implemented around the world, shortening geographic spaces and promoting an expansion of instruction and classroom contexts as local activities to the integration between communities and nations (THORNE, 2006).

Finally, we agree with O'Dowd (2014) that the complexity and the difficulties we have to face when organizing and executing a telecollaborative project may discourage professors wanting to implement this kind of activity in their classes. Nevertheless, it is important to remember that telecollaboration is a clear example of how it is possible to 
articulate foreign language learning in the classroom with experiences in which students have contact with other learners, and these opportunities may be enriching both in linguistic and (inter)cultural perspectives. Lastly, the impact of relationships established through telecollaborative language learning promotes new opportunities to explore possibilities of links among those involved in the globalized world and constitutes in a more and more effective way the field of transcultural and transcontinental telecollaboration.

\section{References}

BEDRAN, P. F. A (re)construção das crenças do par interagente e dos professoresmediadores no teletandem. 2008. Dissertação (Mestrado em Estudos Linguísticos) Instituto de Biociências, Letras e Ciências Exatas, Universidade Estadual Paulista, São José do Rio Preto, 2008.

BEDRAN, P. F. A Formação Inicial do Professor de Línguas no e para o Contexto Virtual e a Construção de Comunidades de Prática. 2012. Tese (Doutorado em Estudos Linguísticos) - Instituto de Biociências, Letras e Ciências Exatas, Universidade Estadual Paulista, São José do Rio Preto, 2012.

BeneDetTI, A. M.; CONSOlO, D. A.; VIEIRA-ABRAHÃO, M. H. Pesquisas em ensino e aprendizagem no Teletandem Brasil: línguas estrangeiras para todos. Campinas: Pontes, 2010.

BRAMMERTS, H. Tandem language learning via the internet and the International E-Mail Tandem Network. In: LITTLE, D.; BRAMMERTS, H. (eds.). A Guide to Language Learning in Tandem via the Internet. CLCS Occasional Paper, 46, p. 9-22, 1996.

BRAMMERTS, H.; CALVERT, M.; KLEPPIN, K. Objectivos e formas de aconselhamento individual. In: DELILLE, K. H.; CHICHORRO, A. F. Aprendizagem autónoma de línguas em tandem. Lisboa: Colibri, 2002. p. 69-79.

CAVALARI, S. M. S. A auto-avaliação em um contexto de ensino-aprendizagem de línguas em tandem via chat. 2009. Tese (Doutorado em Estudos Linguísticos) - Instituto de Biociências, Letras e Ciências Exatas, Universidade Estadual Paulista, São José do Rio Preto, 2009. 
- | Transcultural and Transcontinental Telecollaboration for Foreign Language Learning: proposals and challenges

CARVALHO, K. C. H. P. de; MESSIAS, R. A. L.; DÍAS, A. M. Teletandem within the Context of closely-related languages: A Portuguese-Spanish interinstitutional experience. DELTA - Revista de Documentação e Estudos em Linguística Teórica e Aplicada, v. 31, n. 3, p. 711-728, 2015.

CRANDALL, J. J. El aprendizaje cooperativo de idiomas y los factores afectivos. In: ARNOLD, J. (ed.). La dimensión afectiva en el aprendizaje de idiomas. Tradução de Alejandro Valero. Madrid: Cambridge University Press, 2000. p. 243-260.

ELSTERMANN, A. K. Learner Support in Telecollaboration: Peer Group Mediation in Teletandem. Bochum: Ruhr-Universität, 2017.

EVANGELISTA, M. C. R. G.; SALOMÃO, A. C. B. Mediation in Teletandem: from face to face dialogue to dialogical reflective journals. Pandaemonium Germanicum, v. 22, n. 36, p. 153-177, 2019.

FUNO, L. B. A. Teletandem: um estudo sobre identidades culturais e sessões de mediação da aprendizagem. 2015. Tese (Doutorado em Estudos Linguísticos) - Instituto de Biociências, Letras e Ciências Exatas, Universidade Estadual Paulista, São José do Rio Preto, 2015.

FUNO, L. B. A.; ELSTERMANN, A. K.; ZAKIR, M. A. Observação pedagógica em contexto de aprendizagem telecolaborativa. Calidoscópio, v. 14, n. 3, p. 433-447, 2016.

GARCÍA, J. S.; CRAPOTTA, J. Models of Telecollaboration (2): Cultura. In: O'DOWD, R. (ed.). Online Intercultural Exchange: An Introduction for Foreign Language Teachers. Clevedon: Multilingual Matters, 2007. p. 62-84.

KERN, R. Technology in language learning. In: SIMPSON, J. (ed.). The Routledge Handbook of Applied Linguistics. London \& New York: Routledge, 2013. p. 200-2014.

KERN, R.; WARE, P.; WARSCHAUER, M. Crossing frontiers: new directions in online pedagogy and research. Annual review of Applied Linguistics, 24, p. 243-260, 2004.

LITTLE, D. A aprendizagem de línguas em tandem e a autonomia do aprendente. In: DELILLE, K. H.; CHICHORRO, A. F. Aprendizagem autónoma de línguas em tandem. Lisboa: Colibri, 2002. p. 27-35. 
MESQUITA, A. F. Crenças e práticas de avaliação no processo interativo e na mediação de um par no tandem a distância: Um estudo de caso. 2008. Dissertação (Mestrado em Estudos Linguísticos) - Instituto de Biociências, Letras e Ciências Exatas, Universidade Estadual Paulista, São José do Rio Preto, 2008.

MIGUELA, A. D. Models of telecollaboration (3): eTwinning. In: O'DOWD, R. (ed.). Online Intercultural Exchange: An Introduction for Foreign Language Teachers. Clevedon: Multilingual Matters, 2007. p. 85-104.

O'DOWD, R. (ed.). Online Intercultural Exchange: An Introduction for Foreign Language Teachers. Clevedon: Multilingual Matters, 2007.

O'DOWD, R. Intercultural communicative competence through telecollaboration. In: JACKSON, J. The Routledge Handbook of Language and Intercultural Communication. New York: Routledge, 2014. p. 340-356.

O'DOWD, R. From telecollaboration to virtual exchange: state-of-the-art and the role of UNICollaboration in moving forward. Journal of Virtual Exchange, n. 1, p. 1-23, 2018.

O'ROURKE, B. Models of Telecollaboration (1): eTandem. In: O'DOWD, R. (ed.). Online Intercultural Exchange: An Introduction for Foreign Language Teachers. Clevedon: Multilingual Matters, 2007. p. 41-61.

SALOMÃO, A. C. B. Gerenciamento e estratégias pedagógicas na mediação dos pares no teletandem e seus reflexos para as práticas pedagógicas dos interagentes. 2008. Dissertação (Mestrado em Estudos Linguísticos) - Instituto de Biociências, Letras e Ciências Exatas, Universidade Estadual Paulista, São José do Rio Preto, 2008.

SALOMÃO, A. C. B. A formação do formador de professores: perspectivas de colaboração entre graduandos e pós-graduandos no projeto Teletandem Brasil. Revista Brasileira de Linguística Aplicada [on-line], v. 11, n. 3, p. 653-677, 2011. Disponível em: http://dx.doi. org/10.1590/S1984-63982011000300004. Acesso em: 15 nov. 2018.

SALOMÃO, A. C. B.; SILVA, A. C.; DANIEL, F. de G. A aprendizagem colaborativa em Tandem: um olhar sobre seus princípios. In: TELLES, J. A. Teletandem: um contexto virtual, autônomo e colaborativo para aprendizagem de línguas estrangeiras no século XXI. Campinas: Pontes, 2009. p. 75-92. 
- | Transcultural and Transcontinental Telecollaboration for Foreign Language Learning: proposals and challenges

STICKLER, U. Student-centred counselling for tandem advising. In: LEWIS, T.; WALKER, L. (eds.). Autonomous language learning in tandem. Sheffield, UK: Academy Electronic Publications, 2003. p. 115-122.

TELLES, J. A.; VASSALLO, M. L. Foreign language learning in-tandem: Teletandem as an alternative proposal in CALLT. The ESPecialist, v. 27, n. 2, p. 189-212, 2006.

TELLES, J. A. Teletandem: um contexto virtual, autônomo e colaborativo para aprendizagem de línguas estrangeiras no século XXI. Campinas: Pontes, 2009.

TELLES, J. A. Learning foreign languages in teletandem: Resources and strategies. DELTA Revista de Estudos em Linguística Teórica e Aplicada, v. 31, n. 3, 651-680, 2015.

THORNE, S. L. Pedagogical and Praxiological Lessons from Internet-mediated Intercultural Foreign Language Education Research. In: BELZ, J. A.; THORNE, S. L. (eds.). AAUSC 2005: Internet-mediated Intercultural Foreign Language Education. Boston: Thomson Heinle, 2006.

VASSALLO, M. L.; TELLES, J. A. Foreign language learning in-tandem: Theoretical principles and research perspectives. The ESPecialist, v. 27, n. 1, p. 83-118, 2006.

WILLIAMS, M.; BURDEN, R. Psicología para profesores de idiomas. Enfoque del constructivismo social. Madrid: Cambridge University Press, 1999.

COMO CITAR ESTE ARTIGO: COSTA, Leila Martins Gonçalves da; SALOMÃO, Ana Cristina Biondo; ZAKIR, Maisa de Alcântara. Transcultural and Transcontinental Telecollaboration for Foreign Language Learning: proposals and challenges. Revista do GEL, v. 15, n. 3, p. 26-41, 2018. Disponível em: https://revistadogel.gel.org.br/

DOI: http://dx.doi.org/10.21165/gel.v15i3.2434 